\title{
ANTHROPOGENIC OR ECOLOGICAL TRAP: WHAT IS CAUSING THE POPULATION DECLINE OF THE LAPWING VANELLUS VANELLUS IN WESTERN UKRAINE?
}

\author{
Ihor Shydlovskyy, Hanna Kuzyo*
}

\begin{abstract}
Shydlovskyy I., Kuzyo H. 2016. Anthropogenic or ecological trap: what is causing the population decline of the Lapwing Vanellus vanellus in Western Ukraine? Ring 38: 43-55.

Ecological and anthropogenic traps exist and exert a negative effect on Lapwing populations. We believe that an anthropogenic trap is a partial or delayed manifestation of an ecological trap. In recent decades Lapwing communities have shown higher affiliation with urban landscapes, which negatively influences breeding success and the overall density of the species. It appears that the Lapwing has fallen into an anthropogenic trap, which in Ukraine is represented by agricultural landscapes. The decline in the Lapwing population is mainly caused by high intensity of agriculture, overgrazing, desolation of agricultural lands, changes in the water regime of rivers and lakes, global forestation, increasing disturbance by recreational activity and tourism, and an increase in the distribution and number of predatory mammals. Controlled burns of dead vegetation performed in late spring, household waste disposal, and construction work all contribute to the loss of breeding grounds. As a result the majority of local Lapwing populations declined during last decade, and some populations have gone completely extinct.
\end{abstract}

I. Shydlovskyy Zoological Museum of the Ivan Franko National University of Lviv, Hrushevskyy Str. 4, Lviv 79005, UKRAINE, shydlyk@gmail.com

* H. Kuzyo, State Museum of Natural History of NAS of Ukraine, Teatralna Str. 18, Lviv 79008, UKRAINE,HannaKuzyo@gmail.com

Keywords: anthropogenic trap, ecological trap, population decline, Lapwing

\section{INTRODUCTION}

Life in an anthropogenic environment requires new adaptations and less efficient specialization. Specialized functions usually work best in a stable environment. Ecosystems affected by human activity are characterized by irregular changes in environmental conditions, disrupted nutrient cycles and unstable availability of resources. For this reason large numbers of animals which are unable to adapt to the new, 
human-influenced living conditions and to respond adequately to changes in the environment are doomed to extinction both as individuals and as populations (Zagorodniuk 2003, Zagorodniuk 2006 after Klausnyttser 1990).

Two new terms have appeared in the zoological literature in the past few years: 'environmental trap' and 'the anthropogenic trap'. What is the difference between the two? Our study aims to distinguish between environmental and anthropogenic traps and describe how they are causing the decline in Lapwing populations in Western Ukraine. The main goal of our research is to uncover various factors affecting the breeding success of the Lapwing in Western Ukraine.

The ecological concept of a trap was proposed nearly half a century ago by Dwernychuk and Boag (1972), who suggested that this phenomenon may be common on the planet due to the considerable anthropogenic changes to the environment. One of the fundamental concepts is that an 'ecological trap' created by rapid anthropogenic change can facilitate extinction (Fletcher et al. 2012). According to Battin (2004), a 'habitat trap' is a landscape that would be expected to support a stable population but may instead lead to population extinction (Battin 2004). The concept lies in the fact that species which can actively choose their habitat have to use indirect ecological cues to assess habitat quality. It is possible for humans to alter habitats in a way that causes a discrepancy between the cues and the true quality of different habitats (Kokko and Sutherland 2001). If habitat quality changes in such a way that it does not correspond with reality, species can make a mistake and find themselves in unsuitable habitats. In particular, a population can be caught in a trap when the attractiveness of the environment is overestimated as compared to its resources for reproduction and survival. As a result, deceptively attractive habitats are prioritized by animals. Examples of such habitats include fast-growing crops, human settlements, or farms where animals can cause harm to human property (Korobchenko 2011).

An 'anthropogenic trap' occurs when sudden changes in an ecosystem (caused by human activity) force animals to settle in unsuitable habitats due to the absence of alternatives. Examples of such anthropogenic traps include land with intensive agricultural practices (tillage, sowing, watering, mowing, etc.), buildings, close proximity to roads, etc. The main difference between anthropogenic and ecological traps is that an ecological trap can be caused by human activity that took place much earlier, e.g. a few decades before. This is the type of trap that the Lapwing has fallen into.

I. Zagorodniuk (2006) identified five different ways anthropogenic traps impact fauna in general and synanthropic populations of animals in particular:

1. Success of adventive species. Species which have easily coped with new environments and become synanthropic are in most cases well adapted to anthropogenic traps. Such traps have become part of their new environment. Adventive species appear to be 'satisfied' with the new conditions, in contrast with species native to the area.

2. The main victims. Native fauna species are the most common victims of new conditions. Species whose behaviour is highly specialized are especially vulnerable.

3. Formation of new adaptations. The formation of new species-specific behaviour is a result of artificial selection, including the use of tar by crows, kleptoparasitism, the use of novel sources of food, industrial melanism of butterflies, rat digging, cat climbing, etc. 
4. Artificial selection (evolutionary effects). The survival of a species in an urban landscape depends entirely on its tolerance and adaptation to life in synanthropic conditions. This means that there is a natural selection for tolerance for anthropogenic (synanthropic) conditions.

5. Changes in the properties of successful species. Key characteristics of successful synanthropic species include 1) adaptations to rapid and excessive changes in abiotic conditions supported by behavioural responses (in contrast to reproductive responses); 2) the formation of a dynamic population structure which is able to survive in conditions of excessive spatial fragmentation of environment; and 3) increased learning abilities of foragers dependent on incidental supply of food (kitchen leftovers, roadkill, etc.).

Of the five cases listed above, the forth is characteristic of the Lapwing. The species is selected positively for tolerance to synanthropic conditions. This process progresses at different rates, in different habitats and under the influence of different anthropogenic factors. The process of forestation of Lapwing communities has been actively taking place during the last few decades. Not only are the birds feeding on arable lands, but they have also begun to nest and breed on them. This, in turn, has negatively impacted the breeding success and overall density of the birds. We can say that the Lapwing is in an 'anthropogenic' trap represented by the agricultural landscape. The species attempted to adapt but was not successful due to intensive and unpredictable management of agricultural lands, i.e. intensive use, random crop rotation, tillage, and mowing. In addition, due to desolation and complete abandonment of land after agricultural use since 1993, it has become overgrown by shrubs or ruderal vegetation.

\section{STUDY AREA AND METHODS}

The biology and population density of the Lapwing were studied in 1987-2015 in Western Ukraine (Fig. 1). We used an absolute census for small test sites, a relative census for large areas in the river valleys, a transect census, phenological analysis, and analysis of breeding success and breeding habitat selection by the Lapwing.

The ecosystems of Western Ukraine have suffered most due to intensive land reclamation and drainage of large areas of marshes and wetlands, which resulted in aridification or, to a lesser extent, secondary swamping. The total reclamation area in the Volyn region in 1991 included 845,200 hectares of land, of which 407,000 hectares were already in use. It included such large-scale drainage systems as Kopayivska, Zabolotivska, Turska and Verkhnio-Pripyatska (Fig. 2). These were created in the valleys of the Prypjat and Western Bug Rivers in 1960-1966 and covered an area of more than 50,000 hectares (Balkovskyy 2009). In conditions of moderate and low air moisture, the drainage must be accompanied by artificial watering in order to avoid aridification, soil deflation and water level decline. For example, the use of the Kopayivska water drainage system resulted in a $5-10 \mathrm{~cm}$ decline of the water table in the largest freshwater Ukrainian lake, Lake Svityaz. Moreover, water draining in the upper Prypjat valley resulted in a change in groundwater flow, a decrease in its level and a re- 


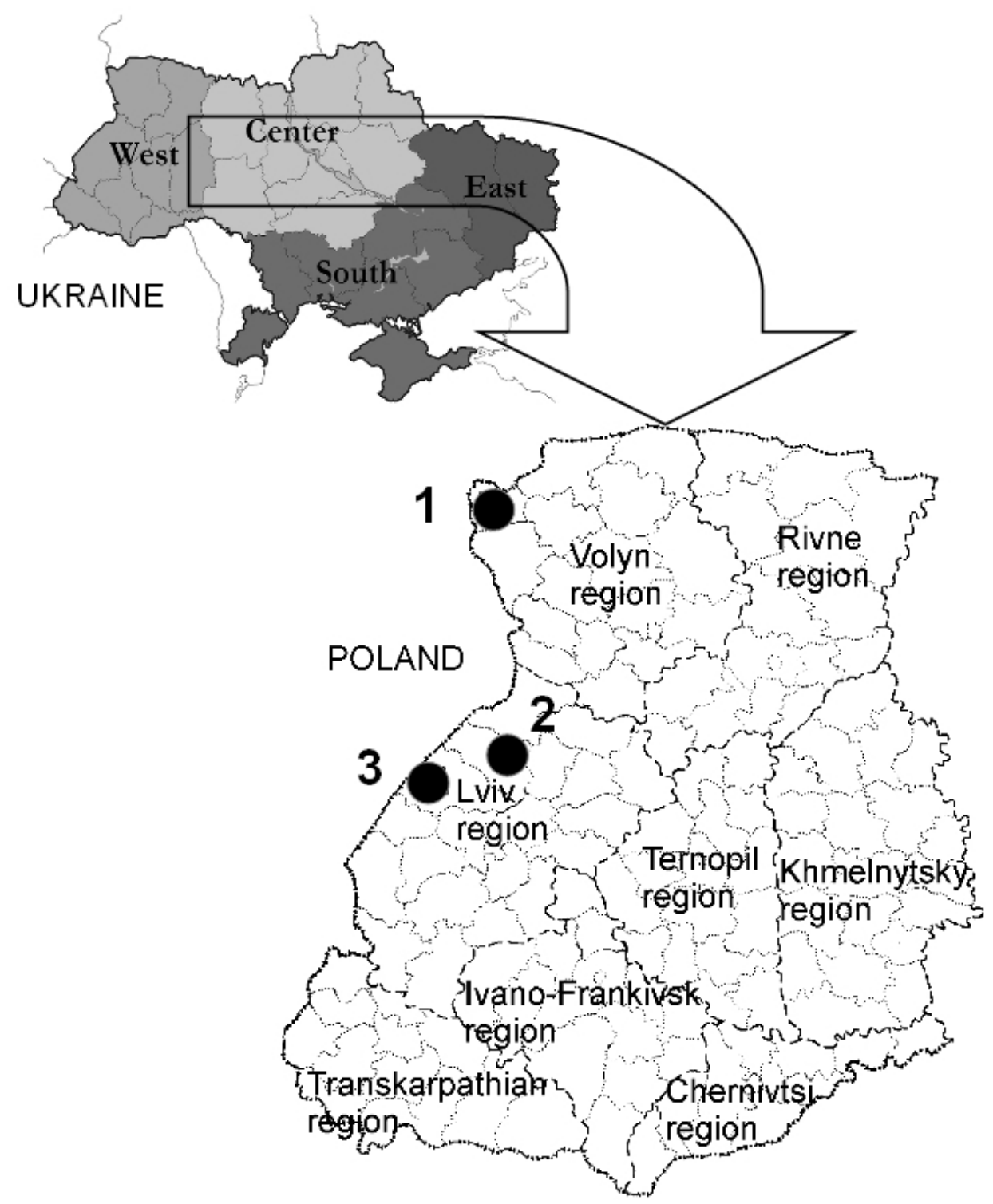

Fig. 1. Main areas of investigation. 1 - Shatsk National Nature Park, 2 - town of Zhovkva, 3 - Cholgyni Nature Reserve

duced pressure gradient. All of these factors slowed the inflow of groundwater into Lake Svityaz by $10 \%$, which undoubtedly changed the structure of lacustrine habitats and affected Lapwing populations. The decrease in the waterline and drought stimulated overgrowth of the lake shoreline with high semiaquatic vegetation (sedges, reeds, rushes, cattails, etc.). Water saturation caused flooding of suitable breeding habitats, delaying oviposition and extending the breeding period, which increased 
competition for suitable breeding habitats between different bird species. This in turn led to the appearance of combined mono- and poly-species clutches (Lapwing + Lapwing, Lapwing + Common Redshank Tringa totanus, Lapwing+Black-tailed Godwit Limosa limosa).

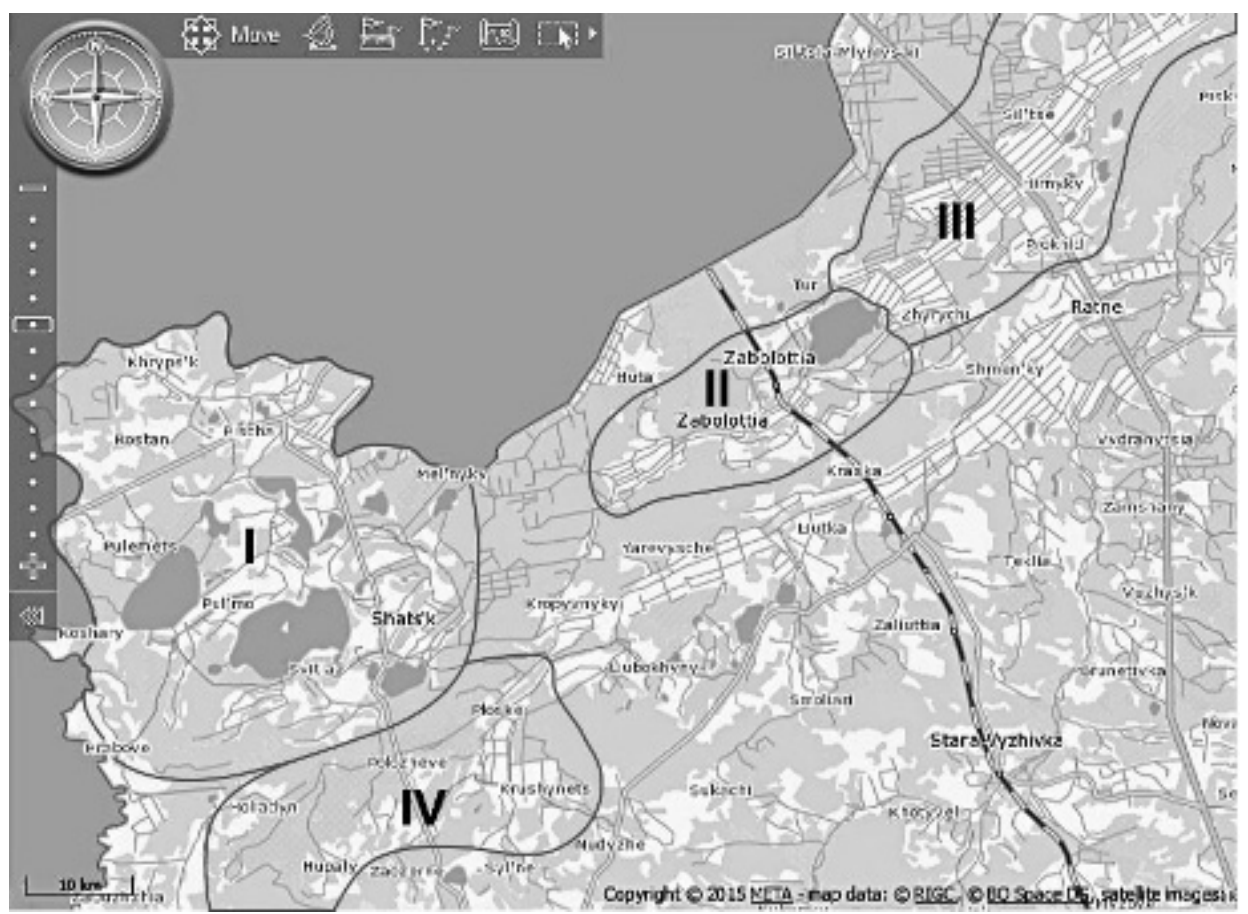

Fig. 2. Drainage systems: I - Kopayivska, II - Zabolotivska, III - Turska and IV - Verkhnio-Pripyatska in the northern part of the Volyn region

Aridification and secondary swamping are commonplace on the agricultural land of Polissya affected by water drainage. They occur as a result of negative changes in the natural water cycle caused by draining of marshes and wetlands (Panas 2004). Recent field and analytical surveys have revealed the presence of aridification on nearly all post-drained areas in Western Polissya (Balkovskyy 2009).

Forestation is another negative effect of water drainage. It is the process of overgrowing of drained lands with trees and shrubs which have low productivity and are unsuitable for human use. These species include willow thickets Salix sp., White birch Betula platyphyla, and less commonly Black alder Alnus glutinosa and Common aspen Populus tremula.

\section{RESULTS AND DISCUSSION}

At the end of the 20th century the Lapwing population within Western Ukraine was estimated at 33,180-36,330 breeding pairs (Horban and Shydlovskyy 1999). 
Breeding of Lapwings was concentrated within the Volyn, Rivne and Lviv regions, where $80 \%$ of the entire West Ukrainian group of the species was breeding. Quite a large number were noted in the vicinity of the Lakes of Shatsk, in the valleys of the Western Bug, Luha, Prypjat, Turija, Stokhid, Styr, Horyn, and Sluch, and also in the Small Polissya and Upper Dnister lowland.

Our data from a decade ago indicated that in most regions of Western Ukraine the Lapwing population has decreased by more than 25\% (Shydlovskyy 2005).

In 2004-2006, most of the small breeding sites of the Lapwing in western regions were disappearing. This phenomenon was clearly evident in agricultural areas (pastures and cereal fields) and small wetland and coastline areas. In places where there were large settlements of breeding Lapwings in the 1980s and 1990s, their numbers have decreased 5-10 times (Tab. 1). This situation is typical both for sites covered by the Nature Reserve Fund and for areas without conservation status, and decreasing trends are also observed in other Ukrainian and European regions. Having had no protection status in the 1990s, in 2004 the species was included in the SPEC 2 category, i.e. vulnerable.

Table 1

Numbers of Lapwing breeding pairs in 1982-2015 on each study plot and in total for Western Ukraine

\begin{tabular}{|c|c|c|c|c|c|c|}
\hline $\begin{array}{l}\text { Observation } \\
\text { sites } \\
\text { Years of } \\
\text { observations }\end{array}$ & $\begin{array}{c}\text { Zhovkva } \\
\text { outskirts } \\
\text { (Lviv } \\
\text { region) }\end{array}$ & $\begin{array}{c}\text { Skoromokhy } \\
\text { outskirts } \\
\text { (Lviv } \\
\text { region) }\end{array}$ & $\begin{array}{c}\text { Gushcha } \\
\text { outskirts } \\
\text { (Western } \\
\text { Volyn) }\end{array}$ & $\begin{array}{l}\text { Shatsk } \\
\text { NNP } \\
\text { (Western } \\
\text { Volyn) }\end{array}$ & $\begin{array}{l}\text { Prypjat- } \\
\text { Stokhid } \\
\text { NNP } \\
\text { (Eastern } \\
\text { Volyn) }\end{array}$ & $\begin{array}{c}\text { Total } \\
\text { Western } \\
\text { Ukraine } \\
\text { (thousands) }\end{array}$ \\
\hline $1982-85$ & $28-35$ & 43 & $70-77$ & $600-840$ & $1300-1550$ & 40 \\
\hline 1992-95 & $17-19$ & 26 & $43-45$ & $250-350$ & $650-900$ & $33-36$ \\
\hline 2002-06 & $5-12$ & $15-16$ & $32-36$ & $130-200$ & $270-330$ & $10-12$ \\
\hline 2007-09 & 0 & no data & no data & $60-80$ & $150-200$ & 6-9 \\
\hline $2010-12$ & 0 & no data & no data & $30-50$ & $80-100$ & $2.5-4$ \\
\hline 2013-15 & $0-2$ & no data & no data & $30-40$ & $80-90$ & $1.4-2.8$ \\
\hline
\end{tabular}

The sharp decline in the abundance of the species is a cause for concern, as censuses have found that the West Ukrainian population of Lapwings is about 20 times smaller than it was 30 years ago. Today, breeding Lapwings have disappeared, or only a few pairs have remained in on the peripheries of large wetlands. Such wetlands include the Unychi swampland in Shatsk National Nature Park, swamps in the upper valley of the Pripjat River (Shatsk district, Volyn region) and in the middle part of the Pripjat valley near the village of Birky, and wetlands in the valley of the Luha River near the city of Volodymyr-Volynskyj (Volyn region).

Table 2 presents data on the average number of breeding Lapwings on particular plots in the Lviv region. High intensity of agriculture, overgrazing, desolation of agricultural lands, changes in the water regime of rivers and lakes, forestation, and increased disturbance due to uncontrolled recreation and tourism are the main reasons for the decline of the Lapwing population. Another serious factor affecting species 
numbers is the considerable expansion and population growth of carnivores, such as stray dogs Canis familiaris and cats Felis catus, which prey in breeding habitats of the Lapwing. Also, the decrease in demand for fur has caused an increase in the populations of Mustelidae and red fox Vulpes vulpes. Extensive controlled burns of dry vegetation decrease the food supply, destroy breeding habitats or delay the breeding period. Pollution of pastures by rubbish, especially near residential areas and roads, has a similar negative impact. As a result, most local Lapwing populations in Western Ukraine suffered a sharp decline during the last decade, while some settlements disappeared completely. Many suitable breeding grounds have disappeared due to construction work.

Table 2.

Average numbers of Lapwing breeding pairs within some sites in the Lviv region in 2008-2014. $N$ - number of breeding pairs; because the numbers of breeding pairs fluctuated from year to year, average values are given.

\begin{tabular}{|c|c|c|c|c|c|c|c|}
\hline & District & Nearest & $\begin{array}{l}\text { Coord } \\
\text { (WGS }\end{array}$ & $\begin{array}{l}\text { nates } \\
1984)\end{array}$ & Area, ha & Bre & ng pairs \\
\hline & & & Latitude & Longitude & & $\mathrm{N}$ & Pairs/10 ha \\
\hline 1 & Sokal & Dobryachyn v. & 50.415989 & 24.244110 & 34.3 & 2 & 0.6 \\
\hline 2 & Zhovkva & $\begin{array}{l}\text { Velyki } \\
\text { Hrybovychi v. }\end{array}$ & 49.919937 & 24.041960 & 7.2 & 5 & 6.9 \\
\hline 3 & & Kamjanobrid v. & 49.835577 & 23.649244 & 9.8 & 2 & 2.0 \\
\hline 4 & & Krakovets v, & 49.956148 & 23.192382 & 26.2 & 3 & 1.1 \\
\hline 5 & Yavoriv & Rosnivka v. & 49.934885 & 23.251437 & 12.3 & 2 & 1.7 \\
\hline 6 & & Vorotsiv v. & 49.865091 & 23.795762 & 13.6 & 5 & 3.7 \\
\hline 7 & & Cholgyni v. & 49.918398 & 23.438842 & $\sim 8$ & 8 & 10.0 \\
\hline 8 & & Cherlyany v. & 49.750728 & 23.683098 & 17.4 & 11 & 6.5 \\
\hline 9 & & Nove Selo v. & 49.582553 & 23.676512 & 1.64 & 5 & 25.0 \\
\hline 10 & & Porichchja v. & 49.716152 & 23.700832 & 16.5 & 3 & 1.8 \\
\hline 11 & & Cherljany v. & 49.778055 & 23.663207 & 9.4 & 4 & 4.6 \\
\hline 12 & & Pidzvirynets v. & 49.572444 & 23.711455 & $?$ & 1 & - \\
\hline 13 & Horodok & Uhry v. & 49.739042 & 23.663089 & $\sim 7$ & 3 & 4.3 \\
\hline 14 & & Zaluzhany v. & 49.713448 & 23.658004 & 44.6 & 2 & 0.4 \\
\hline 15 & & Bratkovychi v. & 49.792757 & 23.582678 & 52.1 & 4 & 0.8 \\
\hline 16 & Busk & Polonychi v. & 49.871832 & 24.361966 & 79.2 & 3 & 0.4 \\
\hline 17 & Sambir & Chajkovychi v. & 49.578041 & 23.538113 & 92.0 & 15 & 1.6 \\
\hline 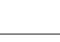 & & Total & - & - & - & 78 & - \\
\hline
\end{tabular}

* data on the Lviv region were kindly provided by I. Strus.

There is a strong human influence causing a decrease in the size of breeding populations of Lapwings in all regions of Western Ukraine. The effect is most noticeable in the Pripyat River valley (Volyn and Rivne regions), which has the largest breeding communities of this species. The estimated number of breeding pairs was approximately 6,000-7,500 before 1989, but only 2,150-2,700 in 1990-1997 (Horban and Shydlovskyy 1999). The reduction in the area of floodplain meadows and pas- 
tures is the main cause of the Lapwing population decline in the Pripyat River valley, while the valley of the Western Bug River and its tributaries Solokija and Rata are also affected by annual controlled burns of grasslands (Gorban et al. 2002). Lapwing populations are also declining in other regions of Ukraine, i.e. in the Ternopil, Transcarpathia (Lugovoy and Potish 1998), Dnipropetrovsk (Bulakhov et al. 2000) and Sumy regions (Lebid et al. 1992).

Anthropogenic factors are also causing changes in the biology of the species. Belarusian ornithologists have discovered that the breeding period of the Lapwing is longer in anthropogenic habitats due to frequent death of clutches. It lasts 30-35 days longer than in the marshlands. Due to human impact, breeding success in anthropogenic habitats is only 20-35\% (Nikiforov et al. 1997). We have observed a similar phenomenon. Very large numbers of Lapwing nests are destroyed during agricultural work on large collective farms. We recorded $100 \%$ losses of the first clutch of Lapwings in agricultural fields in the Volyn, Lviv and Khmelnytsky regions. This occurs most frequently in fields with potatoes, beets, flax or various forage crops for silage. These fields are planted at the same time that the Lapwing lays eggs and begins incubation, leading to the complete destruction of nests. The second clutch is also completely destroyed in potato and beet fields during inter-row cultivation and crop tending. A slightly different situation was characteristic for private plots before 1993. Such small areas were usually cultivated using hand tools and most of the detected nests remained intact. Most of the collective farms collapsed after the adoption of the new law 'On private property' and the resolution 'On the acceleration of land reform and land privatization' by the Verkhovna Rada of Ukraine on 7 February 1992. Large collective farms were divided into many small ones and given into private ownership. The strong negative impact on the breeding success of the Lapwing was due not to the compartmentalization of the habitats, but to increased use of specialized mechanical equipment and machinery, which destroys more clutches and kills more chicks than manual cultivation.

Grazing, which is extensively practiced on the meadows and shores of lakes, is another significant factor impacting the breeding success of Lapwings. Cattle trample nests and chicks and may cause the complete extinction of breeding colonies. We witnessed such a situation in 1993 in the vicinity of Smidyn (Stara Vyzhivka district, Volyn region). Ten Lapwing nests were found in one of the pastures in early April. A few days later cattle were sent to graze on this pasture, causing birds to relocate from optimal nesting sites to the periphery of the pastures, 200-700 m away. Similar cases are frequently observed on some islands of the Pripyat River (Volyn and Rivne regions). Herds of young horses are left grazing on small islands for nearly the entire summer, destroying everything on the ground, including clutches and chicks. Another negative aspect of grazing is associated with cattle herders, and especially their herding dogs. Dogs eat eggs and chicks, while both humans and dogs scare away adult birds, making nests more vulnerable to predation by the Hooded Crow Corvus cornix and Magpie Pica pica.

The degree of negative impact of grazing is highly dependent on the size of pastures and the size of cattle herds. A large number of cattle in a small area of pasture may cause significant harm to birds, whereas small numbers of livestock have a less 
severe influence. Cattle eat shrubs and young trees, as well as grasses. This type of vegetation is able to form sod and grow to over 0.5 meters in height, so its unregulated propagation would lead to overgrowth of pastureland and the loss of the Lapwing's breeding habitat. During the entire monitoring period in the Cholhynskyj ornithological reserve (Lviv region; Fig. 1) we observed a positive effect of grazing on the quality of the breeding habitat. Grazing prevented the area from becoming overgrown with willows Salix sp., reeds Phragmites australis and reed grass Calamagrostis $s p$. However, after the year 2000 succession began and the reserve was almost completely overgrown with Calamagrostis epigeois, creating unfavourable conditions for nesting Lapwings, which left their previously common breeding places. A similar situation was observed in the valley on the shore of Lake Svitiaz (Shatsk National Natural Park (ShNNP)), where about 25 pairs of Lapwings breed every year. A herd of cows grazed here continuously in 1988-1998, controlling the height of the grass on tussocks. However, after grazing was discontinued in 1999, the pastures became sodded and the grass height increased to $0.4-0.7 \mathrm{~m}$. This in turn led to a sharp decrease in bird abundance (2-3 times) in 2000, and in 2002 the Lapwing did not breed there at all. After grazing was discontinued in one of the pastures near Zhovkva (Lviv region), it was quickly populated by foxes, who made their dens in the middle of the pasture and began to control the surrounding areas. As a result, the Lapwing was forced to leave its breeding area.

Desolation of lands and overgrowth by high grass, weeds and shrubs cause a decrease in numbers or the complete extinction of the Lapwing in such habitats. Populations of all species of Charadriiformes declined significantly in the area between Lakes Luky and Peremut (ShNNP) after 1998. Ten nesting pairs of Lapwings, 4 pairs of Common Redshank and 1-3 pairs of Common snipe Gallinago gallinago were recorded in the wet grassland in June 1998. The number of breeding pairs of birds decreased from year to year, and by 2005 had completely disappeared. This was due to large-scale habitat change over large areas of wetlands in the park and other areas of Polissya. The rapid decline in the number of cattle and horses in villages led to the spread of certain types of shrubs and rapid overgrowth of meadows with high and dense grassy vegetation. The Lapwing does not inhabit habitats with grass height of more than $20 \mathrm{~cm}$. Such habitats are also avoided by most other species of waders. Local people do not raise as much livestock, and they are also abandoning traditional management (mowing) of wetlands, which also stimulates overgrowth. Many private land plots which were previously used to grow crops and were breeding sites for the Lapwing are now abandoned and overgrown with weeds. This also affects Yellow wagtail Motacilla flava; the first breeding attempt is often unsuccessful due to the rapid growth of grasses. Therefore, the success of the breeding season depends on habitat availability in the second half of the season (Gilroy et al. 2010). Thus the loss of natural meadows generally poses a threat to biodiversity (Tryjanowski et al. 2011).

A somewhat similar situation was recorded for many Charadriiformes inhabiting the Unychi swampland. For centuries this marshland was known for abundance and diversity of breeding species of waders. Today, unfortunately, this area has changed completely. The main part of the marshland is no longer used by waders, except for Common Snipe, as it is overgrown with tall grass, willow, reeds, and birch and has 
a considerably lower water level than 25-30 years ago. There are small numbers of breeding Lapwing (1-3 pairs), Common Redshank (2-3 pairs) and sometimes one pair of Eurasian Curlew Numenius arquata or Black-tailed Godwit inhabiting the periphery of the marshland. This is a typical situation in many abandoned areas, whose number has increased considerably all over Ukraine in the past two decades. Consequently, the number of unsuitable habitats for the Lapwing has increased.

Observations show that the impact of the Kopayivska reclamation system on the natural park continues today. The modified water regime has caused drainage and forestation of large areas of the national park that originally were open and wet. The number of willows and other species of trees growing on the shores of Lakes Liutsymer, Svitiaz, Luky and Peremut has increased. In some places the wood thicket reaches the shoreline. Due to overgrowth of the shores of Lake Liutsymer with willows and alder, the Lapwing, Common Redshank and Black-tailed Godwit have nearly stopped breeding in the Tsypel wetland and surrounding areas. A very similar situation was noted on the northern and north-eastern shores of Lake Svitiaz and particularly in the Nyz'ke wetland. In addition to the species mentioned above, Little Ringed Plover Charadrius dubius, Black-headed Gull Larus ridibundus and Common Tern Sterna hirundo have also stopped breeding in this area.

Lysenko (1980), in his study on the northern coast of the Azov Sea and in the valley of the Dnieper River, showed the negative impact of human activity on Lapwing populations. These areas are not only used as livestock pastures, but are also under heavy pressure from tourists and fishermen. As a result of this anthropogenic pressure, in some years about $45-50 \%$ of wader nests, including those of the Lapwing, were lost in the Molochnyj and Utlyuks'kyi estuaries. Therefore, human disturbance is one of the most common examples of negative human impact on wildlife. People may disturb birds during recreation, harvesting of plant material, fishing, and hunting. Recreation and hunting affect bird habitats immediately, while the impact of harvesting and fishing is more indirect. People directly affect other organisms in the ecosystem, and not birds directly, but still disturb them in their breeding habitats or in the areas where birds concentrate during seasonal migrations. For example, the losses to migratory birds caused by disturbance by fishermen in the Cholgyni reserve (Lviv region) during one month in 2001 were estimated at 1.3-1.5 million UAH. This is even without considering protected and endangered species, for which compensation costs are significantly higher (The results..., 2002).

The number of controlled burns of old vegetation near human settlements has been increasing over time. They cause temporary loss of important breeding and foraging habitats for birds, or even destroy nests if the burns are done late in the season. These burns destroy suitable breeding habitats and kill large numbers of invertebrates, which are the main food source for the Lapwing. Large areas of farmland along the Krakovets-Lviv and Lviv-Shack highways were completely burned in the spring of 2012. These areas are close to $300 \mathrm{~km}$ in length.

Pollution of Lapwing breeding sites with rubbish increases the pressure on the population of this species. The most common case is when breeding habitats located near populated places are used as a landfill. This attracts a large number of predatory animals and scavengers (both wild and domesticated), which prey on eggs and nes- 
tlings. The list includes dogs and cats, Grey Crows and Magpies, Ravens Corvus corax and Caspian Gulls Larus cachinans, which gather in the landfill areas in large numbers and cause significant damage to settlements of Lapwings. Foxes may also look for food in landfill sites if these are located on the outskirts of human settlements or near forested areas. Today foxes are the most dangerous predators in colonies of waders, including the Lapwing. They are no longer hunted due to the devaluation of fur and the risk of infection with rabies. This animal is also susceptible to synanthropization, as it often inhabits and makes dens in concrete and metal structures, especially near or inside large industrial enterprises that border with or include water bodies where Lapwings can nest. For example, we observed foxes living near the breeding sites of the Lapwing on the Sirka excavation sites near Novoyavorivsk and Novyj Rosdil and near the coal processing plant near Chervonograd. All three sites are located in the Lviv region.

Changes in breeding habitats due to private construction are becoming increasingly common. For example, the construction of private summer houses has begun near the Illichivka meadow by Lake Svitiaz. The appearance of the first houses and numerous visitors in this area exerted a strong negative impact on the fauna due to disturbance and resulted in rapid succession of coastal meadows and marshes. As a result, the meadows became overgrown and avian fauna changed.

The growing private sector intensively promotes the development of recreational infrastructure, especially small private houses designed for tourists. Private construction on the outskirts of cities across Western Ukraine has also led to a reduction and fragmentation of suitable breeding habitats for Lapwings. A very popular recent trend is to build houses separated by considerable distances, in the middle of pastures, or along the shores of rivers and lakes, often surrounded by large fenced areas.

Lapwing populations are declining in many other European countries, including Denmark, France and Latvia. For example, the Lapwing population in Denmark numbered 68,000 individuals in 1970 and over 50,000 in 1980, but only 40,000-50,000 in 1988 (Frikke 1991). In France, the Lapwing population included 39,500-40,000 pairs in 1961 , about 45,000 pairs in $1964,21,000$ pairs in 1979 , and only $14,400-20,300$ pairs in 1987 (Dubois and Maheo 1991).

\section{SUMMARY}

Anthropogenic and ecological traps exist and have a negative impact on Lapwing populations in Western Ukraine. In our opinion an anthropogenic trap is a partial or delayed effect of an ecological trap, with the latter having a broader definition. Anthropogenic changes are unpredictable and cause birds to make mistakes while choosing future breeding sites, thus losing nests or chicks. Agricultural lands with intensive farming or frequent disturbance by humans during soil cultivation and crop management often become such anthropogenic traps for birds. Ecological traps, on the other hand, are characterized by the aftereffects of improper land reclamation (drainage, sodding or forestation), desolation, and plant successions (sodding, forestation, and overgrowth with ruderal vegetation). Since ecological traps can lead to 
a decline in biodiversity, it is especially important to study them. Their origin and prevention are subjects of particular interest.

\section{ACKNOWLEDGEMENTS}

We would like to thank Dr. A. Holovachov (Swedish Museum of Natural History), A. Zatushevskyy (Assistant Department of Zoology, Ivan Franko National University of Lviv), Dr. Yu. Strus (State Natural History Museum of NAS of Ukraine), and I. Starunko (the Studia Biologica journal, Ivan Franko National University of Lviv) for their assistance in preparing this paper and valuable suggestions and assistance with the translation.

\section{REFERENCES}

Anon. 2002. The results of conservation activities of the company. What threatens birds? In: IBA Bulletin. Kyiv. Ukrainian Society for the Protection of Birds. pp. 3-4. (In Ukrainian).

Balkovskyy V.V. 2009. Hyper Drainage and secondary swamping. In: Innovative potential of Ukrainian science - XXI century: Proceedings of participants IV Ukrainian scientific-practic. Conf. Zaporizhzhya, pp. 3-12. (In Ukrainian).

Battin J. 2004. When good animals love bad habitats: ecological traps and the conservation of animal populations. Cons. Biol. 18 (6): 1482-1491.

Bulakhov V.L., Gubkin A.A., Gubkin A.A. 2000. Current status of fauna waders of Dnipropetrovsk region. In: Questions of steppe forestry that forest land recultivatton. Vol. 4. Dnipropetrovsk, pp. 100-108. (In Russian).

Dubois P.J., Maheo R., Hotker H. 1991. Waders breeding on Wet Grassland in France. Bulletin WSG 61: 27-31.

Dwernychuk L.W., Boag, D.A. 1972. Ducks nesting in association with gulls-an ecological trap? Can. J. of Zool. 50: 559-563.

Fletcher R.J. Jr., Orrock J.L., Robertson B.A. 2012. How the type of anthropogenic change alters the consequences of ecological traps. Proc. R. Soc. B. 279: 2456-2552.

Frikke J. 1991. Breeding Waders and Wet Grassland habitats in Denmark. Bulletin WSG 61: 42-49.

Gilroy J.J., Anderson G.Q.A., Grice P.V., Vickery J.A., Sutherland W.J. 2010. Mid-season shifts in the habitat associations of Yellow Wagtail Motacilla flava breeding in arable farmland. Ibis 152 (1): 90-104.

Gorban I., Szydlovskyi I., Khymin M., Prushynskyi M., Gorban L. 2002. Avifaune of the Ukrainian part of upper part of the Bug valley and perspectives of its protection. In: Korytarz ekologiczny doliny Bugu: Stan - Zagrożenia - Ochrona. A. Dombrowski et. al. (eds). Warszawa, pp. 197-218.

Horban I.M., Shydlovskyy I.V. 1999. The number of breeding waders in the west of Ukraine. In: Breeding waders of Eastern Europe - 2000. P.S. Tomkovich, E.A. Lebedeva (eds).] Moscow. Vol. 2, pp. 93-105. (In Russian).

Kokko H., Sutherland W.J. 2001. Ecological traps in changing environments: Ecological and evolutionary consequences of a behaviourally mediated Allee effect. Evol. Ecol. Res. 3: 537-551.

Korobchenko M. 2011. Features of the modern distribution and storage of feed mole-rat Spalax microphthalmus (Mammalia) in eastern Ukraine. In: Zoocenosis - 2011. VI International Scientific Conference biodiversity and the role of animals in ecosystems, 4-6 October 2011. Dnipropetrovsk, pp. 267-270. (In Ukrainian). 
Lebid E.A., Knysh M.P., Khomenko S.V. 1992. Fauna and ecology of waders the Sumy region. In: Problems of conservation and sustainable use of natural resources of Sumy region. Sumy, pp. 76-94. (In Ukrainian).

Lugovoy A.E., Potish L.A. 1998. Breeding fauna and the number of waders Transcarpathian region of Ukraine. In: Breeding waders of Eastern Europe - 2000. P.S. Tomkovich, E.A. Lebedeva (eds) - Moscow. Vol. 1, pp. 103-106. (In Russian).

Lysenko V.I. 1980. Protection of waders in Zaporizhzhya region. In: Materials 2 meeting on "Fauna and ecology of waders" (The new in studying biology and distribution of waders). Moscow, pp. 67-68.

Nikiforov M.E., Kozulin A.V., Grichik V.V., Tishechkin A.K. (eds). 1997. Birds of Belarus at the turn of the twenty-first century: status, number, distribution. Minsk, pp. 54. (In Russian).

Panas R.M. 2004. Soil degradation: causes and ways to eliminate. Ekolhichnyj visnyk 4(26): 9-10. (In Ukrainian).

Shydlovskyy I. 2005. The Lapwing (Vanellus vanellus L.) in the West of Ukraine: biology, population dynamics, biotopic distribution. Ph.D. Thesis on specialty "Zoology". Kyiv: Institute of Zoology of NAS of Ukraine, pp. 20. (In Ukrainian).

Tryjanowski P., Hartel T., Báldi A., Szymański P., Tobolka M., Herzon I., GoŁawski A., Konvička M., Hromada M., Jerzak L., Kujawa K., Lenda M., OrŁowski M., Panek M., Skórka P., Sparks T.H., Tworek S., Wuczyński A., Żmihorski M. 2011. Conservation of farmland birds faces different challenges in western and central-eastern Europe. Acta Ornithologica 46: 1-12.

Zagorodniuk I. 2006. Anthropogenic traps and survival of animals in a transformed environment. In: Tribune-12. Proceedings of the Second International Interdisciplinary Conference on wildlife dedicated to the memory of F.R. Shtilmark. V.E. Boreyko (eds). Kyiv, pp 160-171. (In Ukrainian).

Zagorodniuk I.V. 2003. The wild fauna of Kyiv and the surrounding areas and its urbanization. Vestnik Zoologii 37(5): 60-68. (In Ukrainian). 